\title{
correspondence
}

\section{The nuclear debate}

StR, - I believe Nature is right to enlarge the nuclear debate to the general, international scene but I wonder if both sides can be represented fairly. Döderlein's essay (November 18 , page 202), which presents one side of the issue, needs to be balanced by these points:

- The battle is one-sided. Pro-nuclear propagandists are paid; the opposition is not. Most nuclear "experts" are employed by the nuclear industry, which has money to spend. For example, anti-nuclear forces were outspent four to eight or more times in the six states where initiatives were balloted in November (Science, November 19). Another disquieting factor is that nuclear industry representatives seem to want to exclude biologists, environmentalists and other concerned members of the general public from the controversy. This approach does not generate confidence.

- Your opponent is always "irrational", as I find Döderlcin. I also object to his suggested dichotomy: "reasonable, rational and valid" (or "reasoned, factual and rational") versus "irrational, emotional and ethical". One wonders what Döderlein's definition of rational might be.

- In my opinion humanity should be glad certain persons ". . . play out some of their inner and emotional needs by taking an active part in the nuclear controversy . . . ". These "needs" may be a safety valve for society. Humans resist becoming robots, they have emotions and let us hope they will continue to learn to express them for our collective betterment. Also, "emotional" and "irrational should not be confused; an emotional approach can be disciplined by rationality and even by the scientific method. Emotionlessness is not unjustly linked with death.

- The fact that already ". . . industry gives uncontrolled releases. . of substances which remain toxic for infinite times...", if true, would hardly be an argument for accepting nuclear wastes. Furthermore, all toxic materials do not have the same toxicity and we are not obliged to make an unweighted choice among them.

- Practically all the plutonium present on earth, contrary to Döderlein's implication, has been produced by manmade nuclear reactors. No natural source of plutonium is known although trace quantities have been reported in uranium deposits. Any plutonium that might have existed on the primitive earth (of $4.6 \times 10^{9}$ years ago) would have long since disappeared because of plutonium's relatively short half life.

- "Medical" reactors may be much smaller than the bomb-capacity commercial reactors planned, hence medical reactors and small research reactors are less directly linked to the spread of nuclear weapons. I believe many people, some nuclear experts included, would like to see more nuclear research. We are alarmed by the planned installation of hundreds of big reactors all over the earth without enough research having been done, especially on medical and genetic risks to nuclear workers and the general public. Some of these reactors will contain tonnes of plutonium (see Frank Barnaby, The SIPRI Yearbook, 1976). Inhaling a few microgrammes can kill you.

- Finally, Döderlein asks “. . . can anything short of actual war stop a determined sovereign nation from getting primitive but usable versions of any kind of contemporary weapons technology-nuclear, bacterial, chemical or any other?" I say war could lead to have-not nations getting nuclear and other modern killing techniques, especially if such countries align themselves with the "right" side in the conflict. In this context, both sides would probably be the right side. So, let us try something short of war.

It seems to me that instead of trying to restrict the discussion to experts we should indeed extend it to everyone. This would encourage a human synthesis, an overall approach on world problems that no one discipline or industry can provide. Our capacities for arriving at common solutions will obviously have to be developed. This could be helped by de-specialising scientific and philosophical methodologies, which could be combined and applied to questions such as disarmament, the energy and food crisis and nuclearisation of the earth. A convergence and interaction between science and philosophy is necessary for just solutions and a stable future world, if it is to be democratic.

\section{R. Grantham}

Laboratoire de Biometrie,

Université Claude Bernard,

Lyon I,

69621 Villeurbanne, France

\section{CERN'S project management}

SIR,-In your article of November 25 marking the completion of the CERN $400 \mathrm{GeV}$ SPS you paid rather less attention than might have been expected to the fact that the project has not only comfortcbly exceeded its original specification in several important respects, but has also been completed on time and within its budget. The excellence of CERN's project management is selfevident, but the matter cannot be left there.

It has been said that CERN is an exacting customer both technically and financially, because it takes great pains to define its requirements precisely and because it usually has a clear idea in advance of how much it will need to pay. On the other hand, it can be a cooperative if tough customer, providing technological expertise, advice and highly-qualified personnel to contractors who experience problems during production. The advantages to both sides in this close relationship are obvious, even though the efficient use of outside technological help may sometimes have to be imposed upon an unwilling firm.

Building the SPS has involved the development of working relations with hundreds of firms throughout Europe. Although CERN's contributions to advanced technology and the economic utility of its contracts have been fully documented $^{1,2}$, its influence as a good customer has perhaps been underestimated, if only because the immediate financial gains are almost impossible to quantify. Now that the customer-contractor principle is established as a fundamental concept behind much British research funding, it is essential to re-emphasise the point that the ultimate success of a complex scientific project depends as much upon the competence and scientific expertise of the customer as upon the performance of the contractor.

\section{C. IMRIE}

Department of Physics and Astronomy, University College, London, UK

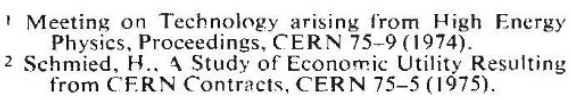
chmied, H.. A Study of Economic Utility Res from CFRN Contracts, CERN 75-5 (1975).

The Editor of Nature welcomes all correspondence. Letters should be kept as brief as possible. 